\title{
Origin of thermal waters from the Hakone geothermal system, Japan
}

\author{
Sadao Matsuo $^{1}$, Minoru Kusakabe ${ }^{2}$, Mariko Niwano ${ }^{3}$, Tomio Hirano ${ }^{4}$ \\ and YASUE OKI ${ }^{4}$
}

\begin{abstract}
Department of Chemistry, Tokyo Institute of Technology, O-okayama, Meguro-ku, Tokyo $152^{1}$, Institute for Study of the Earth's Interior, Okayama University, Misasa, Tottori $682-02^{2}$, Department of Chemistry, Tokyo Kyoiku University, Otsuka, Bunkyo-ku, Tokyo $112^{3}$, and Hot Springs Research Institute of Kanagawa Pref., Hakone-Yumoto 997, Kanagawa 250-03 ${ }^{4}$, Japan
\end{abstract}

(Received June 18, 1984: Accepted August 1, 1984)

In the Hakone geothermal system a variety of waters including precipitation, surface water, ground water, thermal water and steam condensate were analyzed for $\delta \mathrm{D}$ and $\delta^{18} \mathrm{O}$, dissolved sulfate and carbonate for $\delta^{34} \mathrm{~S}, \delta^{18} \mathrm{O}$ and $\delta^{13} \mathrm{C}$, and some sulfur-bearing gases for $\delta^{34} \mathrm{~S}$. Fifteen samples were collected monthly to see if there is any monthly change in the isotopic composition of water. Except in precipitation and steam condensates, no significant monthly changes were observed.

$\delta^{18} \mathrm{O}_{\mathrm{SO}_{4}}$ and $\delta^{34} \mathrm{~S}_{\mathrm{SO}_{4}}$ analyses indicate that surface oxidation of volcanic sulfur produces isotopically light sulfate in water occurring at relatively high elevations. Sulfate minerals in the basement rocks formed by the Miocene submarine volcanism are another source of dissolved sulfate in waters at lower elevations. $\mathrm{CO}_{2}$ originally derived from decomposition of marine carbonate is suggested as a carbon source for dissolved bicarbonate at higher elevations, although contribution of organic carbon becomes significant in waters at lower elevations.

In a $\delta \mathrm{D}$ versus $\delta^{18} \mathrm{O}$ plot, surface waters including precipitation and ground water lie on the line, $\delta \mathrm{D}=8 \delta^{18} \mathrm{O}+17$. On the other hand, thermal waters lie on a regression line, $\delta \mathrm{D}=2.1 \delta^{18} \mathrm{O}-33.5$. Around the intersect of the two lines, $\delta \mathrm{D}=-51 \%$ and $\delta^{18} \mathrm{O}=-8.5 \%$, there is a swarm of point for ground waters. We call the ground water with $\delta \mathrm{D}=-51 \%$ and $\delta^{18} \mathrm{O}=-8.5 \%$ "representative" ground water (RGW). From both chemical and isotopic view points, thermal waters are interpreted to be a mixture of RGW and high temperature dense steam (HTDS), the latter being ultimately evolved from hydrothermal interaction of RGW with rocks containing appreciable amounts of hydrous silicates.

Values of $\delta \mathrm{D}$ and $\delta^{18} \mathrm{O}$ for HTDS have been interpreted to be a result of rock-RGW interaction with the rock/water weight ratio of about 10 , on the basis of isotopic material balance in a closed system with the use of $\delta \mathrm{D}$ of hydrous silicates in rocks as well as $\delta \mathrm{D}$ and $\delta^{18} \mathrm{O}$ values of RGW. When the ratio of about 10 is compared with those of other geothermal areas, the Hakone geothermal system is rock-dominated. Interaction between meteoric water and rocks including hydrous silicates under a rock-dominated condition can account for both hydrogen and oxygen isotopic shifts found in thermal waters.

\section{INTRODUCTION}

Isotopic study, especially that of hydrogen and oxygen isotopes of water is now an essential approach to the origin and behavior of geothermal waters, because geothermal waters are characterized by their isotopic and chemical compositions. Hydrogen and oxygen isotopic ratios of geothermal waters are controlled by a) mixing of meteoric water with various types of water such as sea water, connate water, metamorphic water, and magmatic water, b) altera- tion through water-rock interactions, and c) subsurface boiling. In most cases the above factors contribute to different extents.

The Hakone geothermal system may be one of the best fields to study the hydrological feature of various types of thermal waters, since the caldera can be regarded as an independent hydrological unit. The Hakone volcano, situated $80 \mathrm{~km}$ south-west of Tokyo, is a strato-volcano with double caldera and is composed of three geological units, i.e., old somma, young somma and central cones (Kuno, 1950). The volcanic 
activity started in the late Pleistocene and still continues in the form of fumarolic activity in the Kamiyama and Komagatake (the central cones) with occasional volcanic earthquake swarms. Many hot springs are found along the deep valleys dissected by the rivers Hayakawa and Sukumogawa. The Hakone caldera with dimensions of $11 \mathrm{~km}$ (north-south) and $7 \mathrm{~km}$ (east-west) is morphologically separated from the surrounding area by a distinct old somma (Fig. 1).

A thorough study of the geology of the Hakone volcano and adjacent areas has been made by Kuno $(1950,1951)$. Yuhara et al. (1966) and Yuhara (1968) measured the amount of steam and heat discharge from the active fumaroles, which enabled estimation of the energy output in the Hakone geothermal system. There are a number of chemical studies on thermal waters of this system. Among these, Sato (1962) emphasized a zonal distribution of the thermal waters. Oki and Hirano (1970,
1974) extended the scope and discussed the genetic relationship of thermal waters on the basis of extensive chemical analyses.

Since thermal waters are mostly of meteoric origin (Craig et al., 1956), a better understanding of the isotopic features of the local meteoric water helps interpret the isotopic characteristics of local thermal waters. In this respect, Matsuo et al. (1979) estimated in the Hakone caldera quantitatively the hydrological water budget, using hydrogen and oxygen isotopic composition and chloride content of rain-, river-, lakeand ground-waters of the area.

In this paper we discuss the ultimate origin of thermal waters in the caldera on the basis of isotopic information referring to the previous chemical and hydrological studies.

\section{Samples and Analytical Methods}

About seventy samples were collected from the Hakone caldera for isotopic analyses as

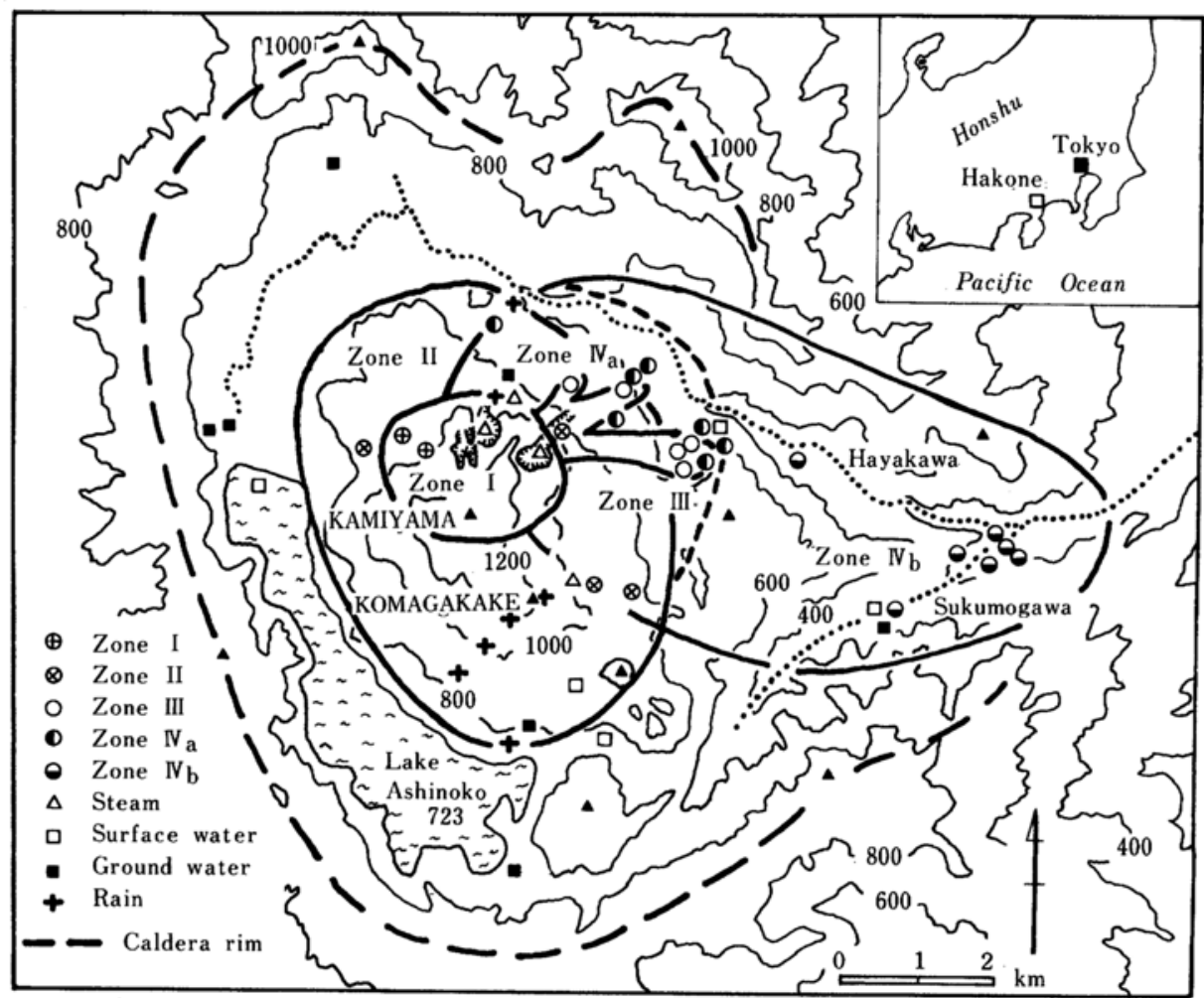

Fig. 1. Sample localities in the Hakone caldera. Heavy lines indicate the zonal distribution of thermal waters with various chemical compositions (after Oki and Hirano, 1970). 
described in Table 1. They are precipitation, river and lake water, ground water, thermal water from the four zones in the caldera which were proposed by Oki and Hirano (1970) and steam condensates from steam wells and fumaroles. Fifteen samples with asterisks in Table 1 were collected once a month from May 1971 to May 1972 in order to see if there were any seasonal variations. These samples were chosen so that they cover the various types of waters occurring in the caldera.

Figure 1 shows sampling localities in the Hakone caldera with the zonal distribution of thermal waters. In Table 1 are included isotopic analyses, water temperature, $\mathrm{pH}$ values, chloride contents, sampling localities with altitude above sea level, and the registered numbers for thermal waters (numbered by Kanagawa Prefecture). It should be noted that the in situ $\mathrm{pH}$ value is certainly not retained, since most of the thermal waters are discharged by an air-lift pump. Condensates from steam wells and fumaroles were collected by sucking steam through a cold trap with the help of a manually operated pump. Some rock samples from the Yugashima group, the basement rocks consisting of thick piles of submarine pyroclastic sediments of the Miocene age, were analyzed for $\mathrm{D} / \mathrm{H}$ ratio in order to estimate the extent of interaction between the thermal water and rocks.

$\mathrm{D} / \mathrm{H}$ ratio analyses of water samples were carried out by passing 5 to $10 \mathrm{mg}$ of water over uranium metal heated to $700^{\circ} \mathrm{C}$ (Bigeleisen et al., 1952) and comparing $\mathrm{D} / \mathrm{H}$ ratio of the resulting hydrogen with that of the standard hydrogen on a mass spectrometer with a dual-inlet and dual-collector system. Hydrogen extraction from hydrous silicates in rock samples was made in the following way. Each sample was powdered, dried and then loaded in a platinum crucible, and hydrogen in the form of water was extracted by means of induction heating in vacuum at $1,200^{\circ} \mathrm{C}$ after absorbed and interlayer water had been removed at $200^{\circ} \mathrm{C}$ (Savin and Epstein, 1970). A small amount of $\mathrm{H}_{2}$ gas formed during heating was converted to $\mathrm{H}_{2} \mathrm{O}$ through a $\mathrm{CuO}$ furnace and the $\mathrm{H}_{2} \mathrm{O}$ recovered was combined with the water evolved as water vapor. The water thus collected was analyzed for $\mathrm{D} / \mathrm{H}$ ratio in the manner described for water samples. ${ }^{18} \mathrm{O} /{ }^{16} \mathrm{O}$ ratio of water samples was measured by the established $\mathrm{CO}_{2}-\mathrm{H}_{2} \mathrm{O}$ exchange technique, followed by the mass spectrometric measurement. Both isotopic ratios are presented in the $\delta$-notation with SMOW as the standard. The overall error was $\pm 1.3 \%$ (one sigma) for $\delta \mathrm{D}$ and $\pm 0.2 \%$ (one sigma) for $\delta^{18} \mathrm{O}$.

For carbon and sulfur isotopic analyses of the dissolved materials, 1 to 2 liters of water samples were taken into plastic bottles to which a small amount of mercuric chloride had been added to suppress any biological activity after collection. Dissolved sulfate was precipitated as $\mathrm{BaSO}_{4}$ for which $\delta^{18} \mathrm{O}_{\mathrm{SO}_{4}}$ and $\delta{ }^{34} \mathrm{~S}_{\mathrm{SO}_{4}}$ analyses were made on $\mathrm{CO}_{2}$ and $\mathrm{SO}_{2}$ gases respectively, obtained by using the preparation techniques described by Rafter (1957), Mizutani (1971) and Robinson and Kusakabe (1975). Sulfurbearing gases from steam wells were recovered in the following manner; steam was introduced into a water-cooled alkaline solution containing cadmium acetate, and the cadmium sulfide thus formed and other sulfur species in higher oxidation state remaining in the solution were recovered for sulfur isotopic analyses.

The total dissolved carbonate was extracted from the samples by acidifying a solution in vacuum with concentrated phosphoric acid (Deuser and Hunt, 1969), and $\delta^{13} \mathrm{C}$ values of the resulting $\mathrm{CO}_{2}$ were determined mass spectrometrically.

\section{General Features and Monthly Variation of Isotopic Ratios}

The results of hydrogen and oxygen isotopic analyses of the water samples are presented in Fig. 2. In Fig. 2 we draw a straight line representing the relationship between $\delta \mathrm{D}$ and $\delta^{18} \mathrm{O}$ of meteoric water in Japan proposed by Sakai and Matsubaya (1974), i.e., $\delta \mathrm{D}=8 \delta^{18} \mathrm{O}+17$. It is seen in Fig. 2 that the average rain and most of ground water samples in the Hakone caldera fit quite well the straight line. Likewise, a 


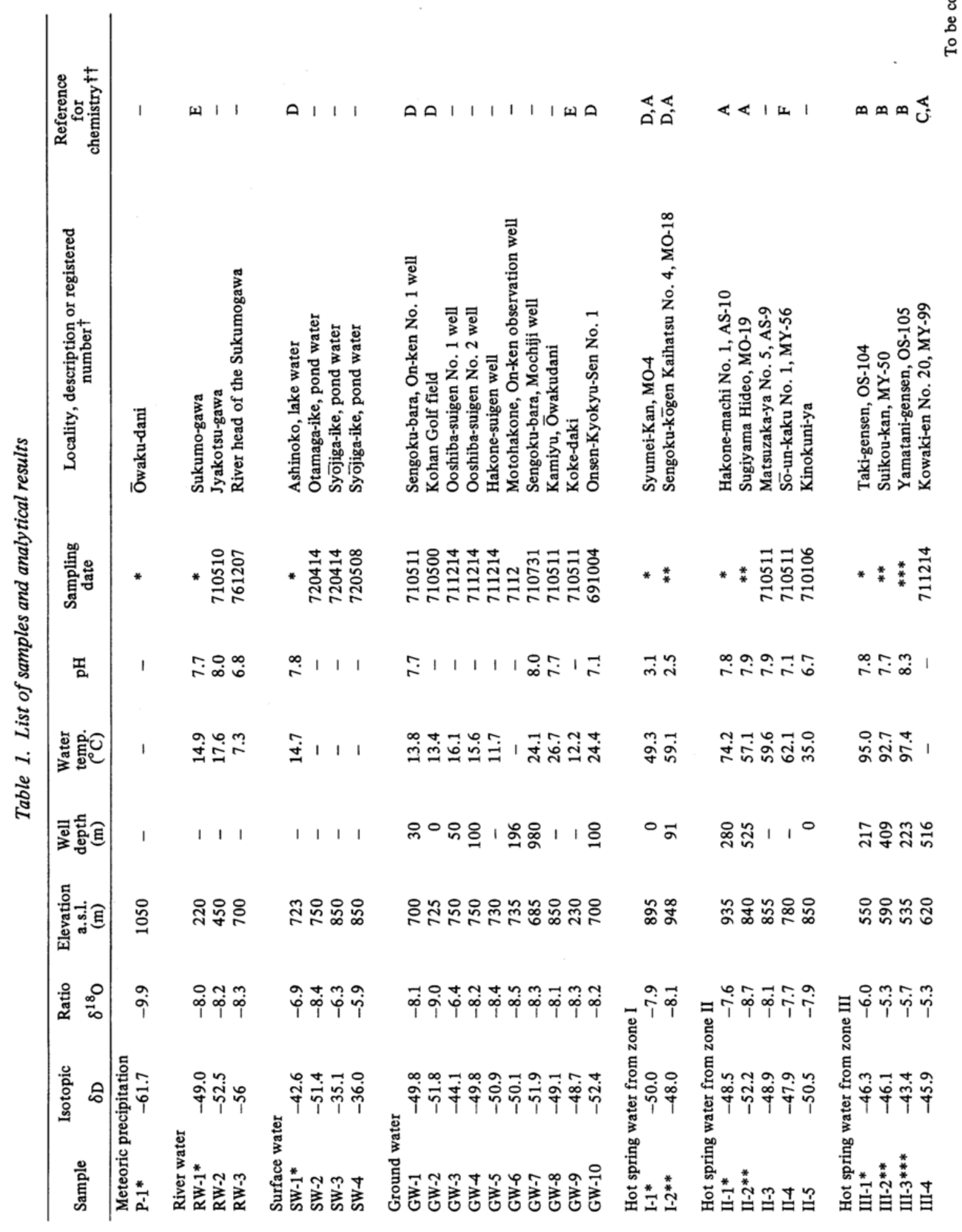




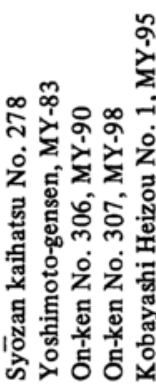

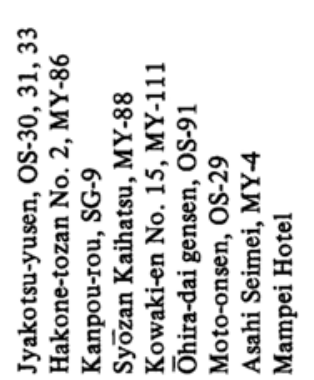

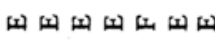

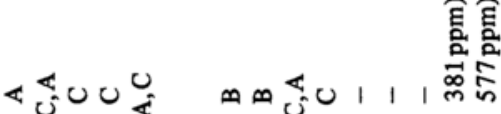

छृ పే

不

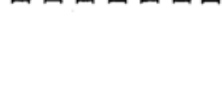
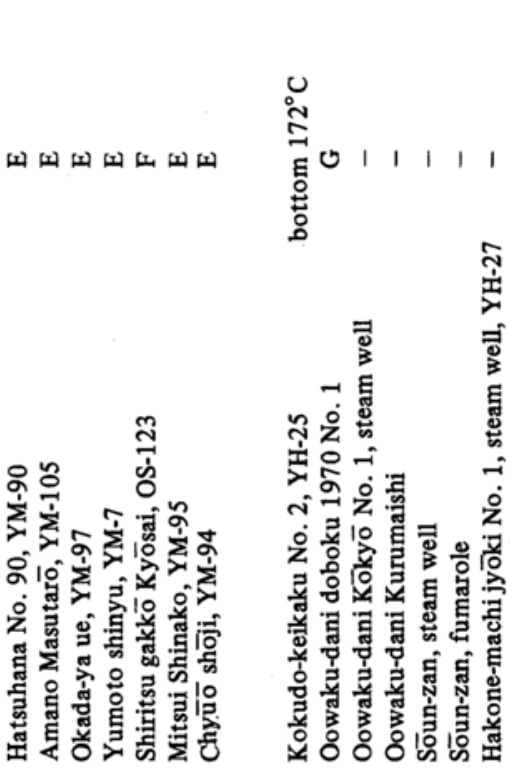

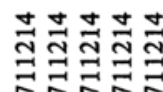

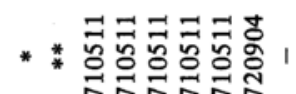

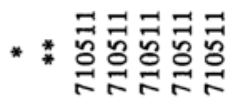

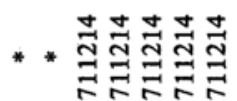

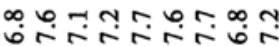

@ి

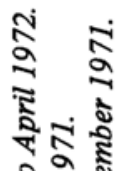
5 일

돈

ำ

।

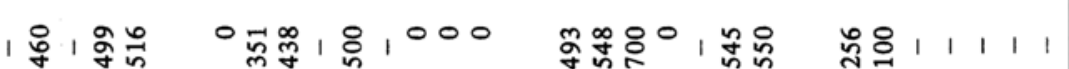
ड़े :

हो हे

है हैं हें

ขึ ฐ

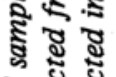

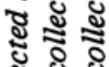

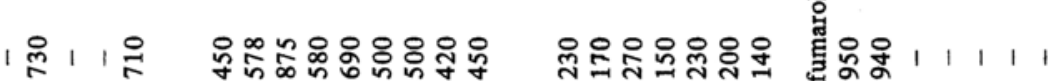

ปั

సे हू ह

ฐิ

$\frac{2}{2}$

ฐ

ปั

ڤे

ปี

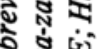

을

ำ

ำ

เัฐ

ริ ธิ

ปิ

过

혼종

ชิ ซิ

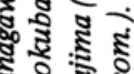
ब

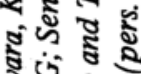

ป

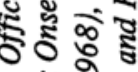

s

สำ ปั

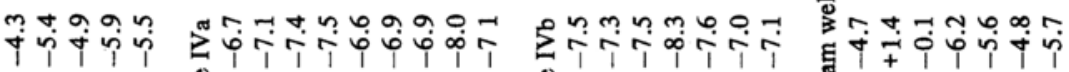

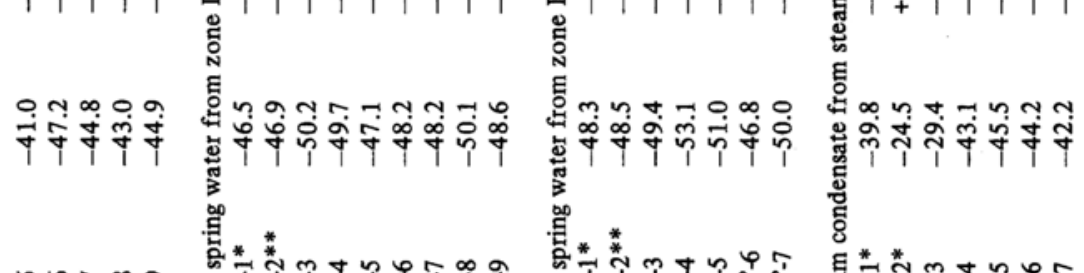

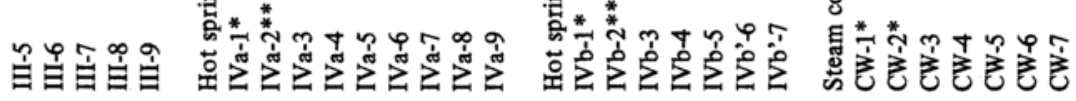

ธี ะ

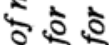

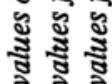

ช จ

离

วิ.

ช.

ड़े डิ

डิ

ख

ะ

हิ

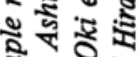

हैं से

*** $*$ t 
straight line, $\delta \mathrm{D}=2.1 \delta^{18} \mathrm{O}-33.5$, can be drawn by the least squares best fit method for all the thermal waters except steam condensates. The two lines intersect at $\delta \mathrm{D}=-51 \%$ and $\delta^{18} \mathrm{O}=$ $-8.5 \%$. There is a swarm of points of ground water centered at this point which we call "representative ground water" (RGW) hereafter. It is seen in Fig. 2 and Table 1 that $\delta \mathrm{D}$ and $\delta^{18} \mathrm{O}$ values of the surface water having open surface such as lake water (SW-1) and pond waters (SW$3,-4)$ are higher than those of most of the ground and thermal waters, and the isotopic enrichment relative to $\mathrm{RGW}$ is most likely to be due to kinetic evaporation.

If the line for thermal waters, $\delta \mathrm{D}=2.1 \delta^{18} \mathrm{O}$ - 33.5, represents a mixing line of RGW with another component, the latter, presumably a high temperature water, should lie somewhere along the thermal water line in Fig. 2. This idea will be pursued in the later section.

One of the purposes of this study is to see whether or not any systematic change in isotopic ratios of monthly collected water of various types exists. The results of hydrogen and oxygen isotopic analyses of monthly collected samples are given in Tables 2 and 3 , respectively. The isotopic variation is the gratest for precipitation. The variation with month in $\delta \mathrm{D}$ and $\delta^{18} \mathrm{O}$ of the other waters is almost equal to or slightly greater than the accuracy of measurement except for the two steam condensates. This means that the monthly fluctuation in precipitation has been smoothed out under the ground (Matsuo et al., 1979). The same conclusion has been obtained in the Nasu volcanic area, Japan (Kusakabe et al., 1970).

The discharge rate of $\mathrm{I}-1$ hot spring, spouting from the slope of a central cone, is known to be positively correlated with precipitation intensity, and the water temperature and salt concentration are inversely correlated (Hirano and Tajima, 1969; Hirota and Odaka, 1975). The isotopic ratios, however, show practically no monthly fluctuation, and the annual averages of $\delta \mathrm{D}$ and $\delta^{18} \mathrm{O}$ values are only slightly higher than those of the precipitation by about $10 \%$ and

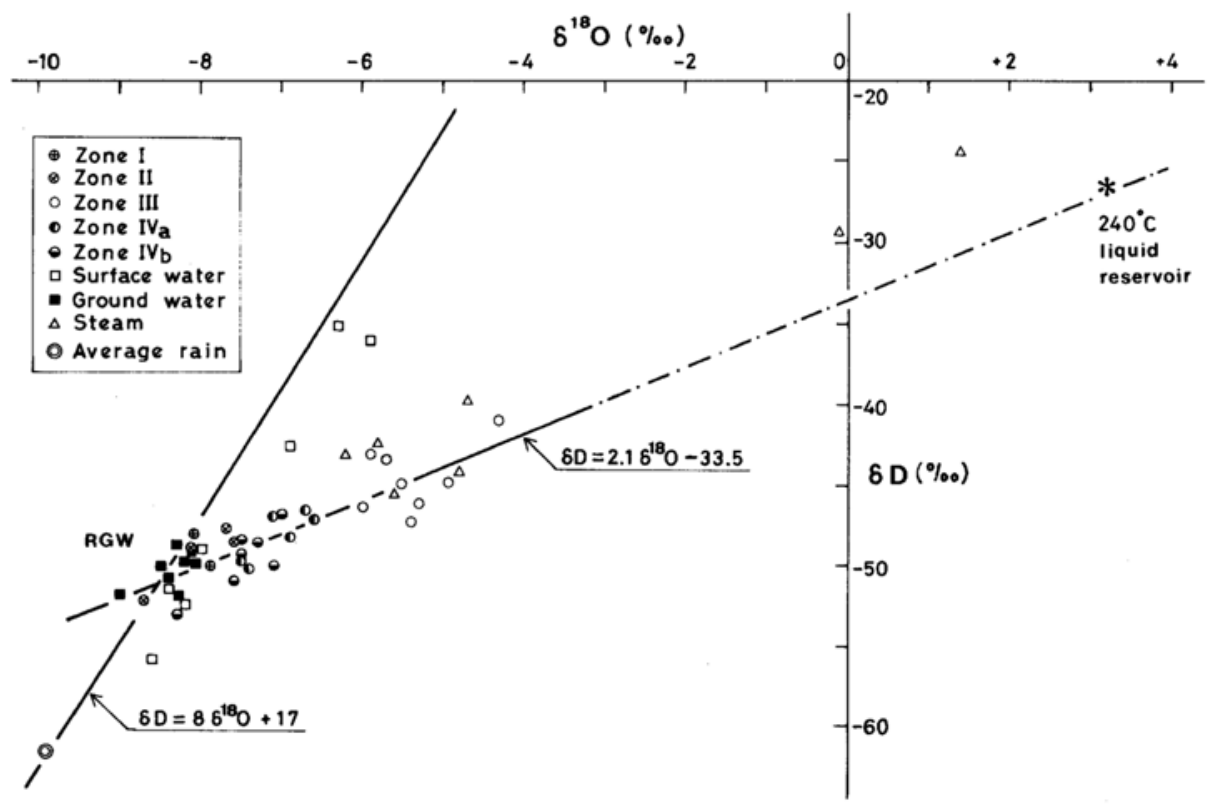

Fig. 2. $\delta D$ versus $\delta^{18} \mathrm{O}$ plot of the Hakone water samples. The isotopic compositions of thermal waters excluding steam condensates are best approximated by a least square regression equation, $\delta D=2.1 \delta^{18} \mathrm{O}-33.5$. The isotopic compositions of the representative ground water $(R G W)$ are defined by the intersection of the thermal water line and the meteoric water line, $\delta D=8 \delta^{18} O+17$. A point at the far-right end of the thermal water line indicates the isotopic composition of the hot water reservoir occurring below the active fumarolic areas of the Hakone volcano. 
Table 2. Variation with time in hydrogen isotope ratio of monthly collected samples and precipitation depth

\begin{tabular}{|c|c|c|c|c|c|c|c|c|c|c|c|}
\hline $\begin{array}{l}\text { Sampling } \\
\text { date }\end{array}$ & P-1 & $\begin{array}{c}\text { Amount } \\
(\mathrm{mm})\end{array}$ & RW-1 & SW-1 & I-1 & II-1 & III-1 & IVa-1 & IVb-1 & CW-1 & CW-2 \\
\hline \multicolumn{12}{|l|}{1971} \\
\hline May & - & - & -48.9 & -42.7 & -50.7 & -44.6 & -44.2 & -45.3 & -48.9 & -47.2 & -24.1 \\
\hline June & -68.0 & 220 & -49.3 & -42.4 & -51.7 & -46.5 & -47.9 & -45.7 & -49.1 & -45.8 & -24.6 \\
\hline July & -71.1 & 184 & -49.1 & -41.7 & -51.1 & -52.3 & -47.1 & -44.6 & -49.1 & -42.1 & -22.6 \\
\hline August & -38.2 & 141 & -49.4 & -42.4 & -49.0 & -49.7 & -46.9 & -46.2 & -47.7 & -41.7 & -25.0 \\
\hline Sept. & -60.4 & 645 & -50.2 & -42.8 & -50.8 & -49.4 & -46.5 & -46.6 & -48.8 & -39.0 & -26.7 \\
\hline Oct. & -52.9 & 309 & -47.2 & -42.3 & -50.0 & -46.7 & -46.2 & -47.7 & -48.6 & -32.5 & -22.5 \\
\hline Nov. & -79.6 & 289 & -50.4 & -43.9 & -50.0 & -48.3 & -46.5 & -46.6 & -47.6 & - & -30.5 \\
\hline Dec. & -49.0 & 29 & -47.9 & -41.3 & -50.0 & -47.1 & -45.3 & -47.3 & -48.4 & -23.6 & -19.3 \\
\hline \multicolumn{12}{|l|}{1972} \\
\hline Jan. & -82.0 & 238 & -51.5 & -42.5 & -51.1 & -50.3 & -46.4 & -46.8 & -46.9 & -45.3 & -26.3 \\
\hline Feb. & -62.0 & 152 & -48.5 & -42.4 & -48.6 & -47.8 & -47.7 & -47.9 & -49.3 & -43.7 & -24.0 \\
\hline March & -67.9 & 74 & -48.2 & -44.4 & -47.9 & -51.6 & -44.0 & -46.4 & -47.5 & -37.1 & -23.2 \\
\hline April & -46.1 & 262 & -47.4 & -42.4 & -49.4 & -47.6 & -46.8 & -47.1 & -47.6 & -40.0 & -25.0 \\
\hline May & -46.5 & $>115$ & & & & & & & & & \\
\hline average & $-61.7 *$ & - & -49.0 & -42.6 & -50.0 & -48.5 & -46.3 & -46.5 & -48.3 & -39.8 & -24.5 \\
\hline $\begin{array}{l}\text { standard } \\
\text { deviation }\end{array}$ & - & - & 1.1 & 0.8 & 1.1 & 2.1 & 1.2 & 0.9 & 0.8 & 6.5 & 2.6 \\
\hline
\end{tabular}

* weighted for precipitation amount.

Table 3. Variation with time in oxygen isotope ratio of monthly collected samples and chloride content of meteoric precipitation

\begin{tabular}{|c|c|c|c|c|c|c|c|c|c|c|c|}
\hline $\begin{array}{c}\text { Sampling } \\
\text { date }\end{array}$ & P-1 & $\begin{array}{c}\mathrm{Cl} \\
(\mathrm{ppm})\end{array}$ & RW-1 & SW-1 & $\mathrm{I}-1$ & II-1 & III-1 & IVa-1 & IVb-1 & CW-1 & CW-2 \\
\hline \multicolumn{12}{|l|}{1971} \\
\hline May & - & - & -7.9 & -7.4 & -8.3 & -7.7 & -5.5 & -7.0 & -7.6 & -6.0 & +1.2 \\
\hline June & -10.5 & - & -8.4 & -7.3 & -8.0 & -8.1 & -6.0 & -6.8 & -8.0 & -5.0 & +1.4 \\
\hline July & -9.9 & - & -7.7 & -7.4 & -8.4 & -7.8 & -6.2 & -6.8 & -7.6 & -4.1 & +1.6 \\
\hline August & -5.4 & 3.0 & -7.5 & -6.4 & -8.2 & -7.9 & -6.2 & -6.7 & -7.8 & -4.2 & +0.8 \\
\hline Sept. & -9.4 & - & -8.2 & -7.4 & -7.9 & -6.9 & -6.0 & -6.4 & -6.3 & -4.0 & +1.9 \\
\hline Oct. & -8.7 & 2.3 & -8.2 & -7.1 & -7.5 & -7.6 & -6.2 & -7.1 & -7.5 & -3.9 & +1.1 \\
\hline Nov. & -12.2 & 1.6 & -8.0 & -6.6 & -7.8 & -7.2 & -5.7 & -6.6 & -7.6 & - & +1.1 \\
\hline Dec. & -9.6 & 5.8 & -8.3 & -6.7 & -7.9 & -7.1 & -6.2 & -6.4 & -7.6 & -2.4 & +1.9 \\
\hline \multicolumn{12}{|l|}{1972} \\
\hline Jan. & -13.4 & 1.4 & -7.5 & -6.2 & -7.8 & -7.5 & -6.1 & -6.5 & -6.8 & -5.1 & +1.5 \\
\hline Feb. & -11.5 & 1.3 & -8.7 & -6.9 & -7.8 & -7.7 & -6.1 & -6.7 & -7.8 & -5.5 & +1.4 \\
\hline March & -11.5 & 2.4 & -7.7 & -6.4 & -7.1 & -7.8 & -5.8 & -6.3 & -7.7 & - & +2.3 \\
\hline April & -8.2 & 2.5 & -8.0 & -7.0 & -8.4 & -7.7 & -6.5 & -6.8 & -8.1 & -5.4 & +1.0 \\
\hline May & -7.0 & - & & & & & & & & & \\
\hline average & $-9.9 *$ & $2.1^{*}$ & -8.0 & -6.9 & -7.9 & -7.6 & -6.0 & -6.7 & -7.5 & -4.6 & +1.4 \\
\hline $\begin{array}{l}\text { standard } \\
\text { deviation }\end{array}$ & - & - & 0.4 & 0.4 & 0.4 & 0.3 & 0.3 & 0.2 & 0.5 & 1.0 & 0.4 \\
\hline
\end{tabular}

* weighted for precipitation amount.

$1 \%$, respectively. Considering a relatively large annual isotopic variation in precipitation (P-1 in Tables 2 and 3), we can conclude that I-1 is an essentially well-mixed ground water of shallow depth discharged by the water-head built up by precipitation.

A large monthly variation has been found for a steam condensate, $\mathrm{CW}-1$. The steam tem- perature ranged from 93 to $123^{\circ} \mathrm{C}$. The sample consisted of steam and mist. Steam discharge was made each time only for sampling with different extent of valve opening, which may determine the outlet steam temperature. In addition, there is no relationship between isotopic values of steam and outlet temperature of steam. This implies that the mist to steam 
ratio in each sample is not related to the measured outlet temperature. The observed monthly isotopic variation may be a reflection of secondary factors during sampling and not be related to the real variation in the original thermal water.

We see in this section that monthly change in isotopic ratios of water in the caldera is negligible except for precipitation and steam condensates. It can be safely said that thermal and ground waters collected at an arbitrary time of year have isotopic compositions close to the annual averages. In the following discussion, we will use one-shot samples together with the averages of monthly collected samples with an equal weight.

\section{BeHAVIOR OF SURFACE AND GRound WATER IN THE CALDERA}

In order to reveal more detailed isotopic features of surface and ground water in the caldera, we collected rain water samples from September 9 to October 20,1971 at five different altitudes on the south-western slope of Komagatake (one of the central cones) from 730 to $1,350 \mathrm{~m}$ elevation at about $200 \mathrm{~m}$ intervals. The result of $\mathrm{D} / \mathrm{H}$ measurement is given in Table 4. It is seen in Table 4 that $\delta \mathrm{D}$ decreases about $1 \%$ per $100 \mathrm{~m}$ at this particular site. This rate is about one fourth to one half of the rates in the Alps (Moser and Stichler, 1970) and the Sierra Nevada (Friedman and Smith, 1970, 1972), probably reflecting the smaller size of the field investigated. So we do not take into consideration the change in isotopic ratios of precipitation with altitude and we will use the annual average values of $\delta \mathrm{D}=-61.7 \%$ and $\delta^{18} \mathrm{O}=-9.9 \%$ (Table 1 ) for isotopic ratios of the precipitation supplied to the caldera.

The values of $\delta \mathrm{D}$ and $\delta^{18} \mathrm{O}$ of ground water (almost the same as those of RGW) are distributed in a narrow range and are practically independent of their altitudal and lateral position in the caldera. In other words, ground water in this caldera is isotopically homogeneous. However, $\delta \mathrm{D}$ and $\delta^{18} \mathrm{O}$ values of ground
Table 4. Altitude effect on $\delta D$ of precipitation $o b$ served at south-western slope of the Komagatake

\begin{tabular}{ccc}
\hline $\begin{array}{c}\text { Altitude } \\
(\mathrm{m})\end{array}$ & $\begin{array}{c}\delta \mathrm{D} \\
(\%)\end{array}$ & $\begin{array}{c}\text { Precipitation } \\
\text { amount (mm) }\end{array}$ \\
\hline 730 & -65.9 & 405 \\
920 & -68.5 & 397 \\
1050 & -72.3 & 438 \\
1190 & -72.2 & 496 \\
1350 & -70.8 & 492 \\
$780^{*}$ & -66.3 & 478 \\
\hline
\end{tabular}

* collected at Shimoyu Earthquake Observatory, Gōra, Hakone.

water are definitely higher than those of the average precipitation. This indicates that the annual average of isotopic composition of precipitation fluctuates with year and/or the average precipitation has undergone enrichment of heavy isotopes through evaporation and evapotranspiration during the formation of the homogenized ground water (Matsuo et al., 1979).

The annual averages of isotopic ratios of the lake water are $\delta \mathrm{D}=-43 \%$ and $\delta^{18} \mathrm{O}=-7 \%$, which are even much higher than those of RGW. The possibility that RGW is a mixture of the lake water and average precipitation is unlikely because ground waters with $\delta \mathrm{D}$ values almost equal to that of RGW can be found even at topographically higher levels than the lake. The permeable pumice formation extending towards the lake bottom is found at the uppermost region of the Sukumogawa River. The water sample (RW-3) collected in this area has isotopic values not close to those of the lake water, but to RGW. This indicates that no appreciable subsurface leakage of lake water occurs. There is a possibility, however, that the bottom water of the lake is isotopically different from the surface water which was actually sampled, and the bottom water is the major source of the ground water in the caldera. In order to check this possibility, a $\delta \mathrm{D}$ profile at the deepest point of the lake was measured in June 1971 when the thermal stratification started. The water samples from $0,10,20,30$ and $38 \mathrm{~m}$ (almost the bottom) showed no appreciable vertical change in $\delta \mathrm{D}$ values which were $-41.5,-41.5,-42.0$ 
-44.1 and $-42.8 \%$ respectively. It should be concluded that no sizable contribution of the lake water to ground water is expected, though the lake water is the largest surface water reservoir in the caldera.

\section{Relationship between Chemical ZoNing AND ISOTOPIC CoMposition of HoT SPRING WATERS}

As mentioned already, Oki and Hirano (1970) divided the occurrence of thermal waters into the four zones according to anion composition of the waters (see Figs. 1 and 3 ).

Zone I waters have low $\mathrm{pH}$ values (2 3) and high sulfate ion concentrations. They are located near the top level of the Kamiyama, one of the central cones (see Fig. 1) and have $\delta \mathrm{D}$ and $\delta^{18} \mathrm{O}$ values as low as those of ground waters (Table 1).

Zone II waters are characterized by high $\mathrm{pH}$ values $(\sim 8)$, and high bicarbonate and sulfate ion concentrations. Zone II waters are pumped from depths of several hundred meters around the central cones. According to Oki and Hirano (1970), the waters may come from a major aquifer beneath the central cones. As seen in

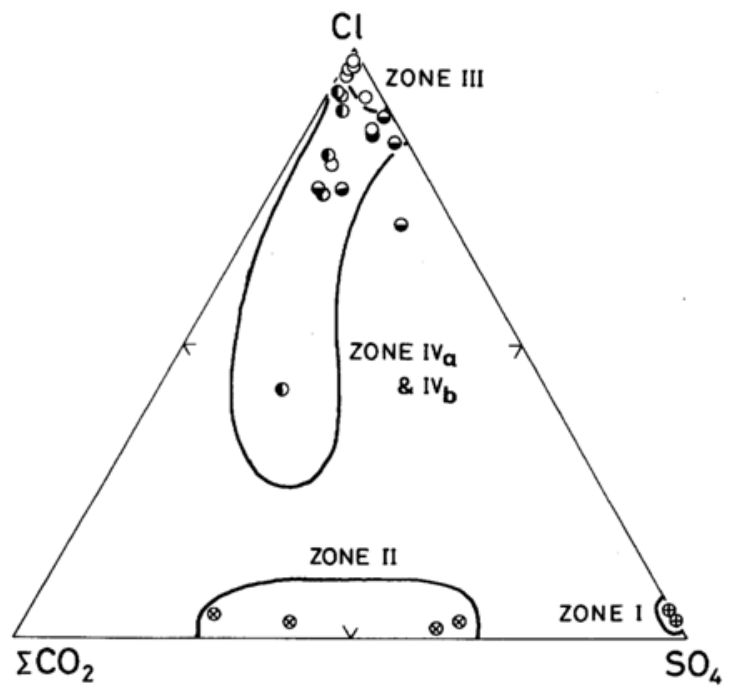

Fig. 3. Anion composition of the thermal waters studied with respect to the zonal distribution (Oki and Hirano, 1970). The symbols are the same as those in Figs. 1 and 2.
Fig. 2, Zone I and II waters can be regarded as ground water in origin. Zone I water extracted $\mathrm{SO}_{4}^{2-}$ and Zone II water extracted $\mathrm{HCO}_{3}{ }^{-}$from central cone materials without significant isotopic exchange. The origin and behavior of $\mathrm{SO}_{4}^{2-}$ and $\mathrm{HCO}_{3}^{-}$will be discussed in the next section

Zone III waters are represented by high temperatures (near boiling point) and intermediate $\mathrm{pH}$ values, major constituent being sodium chloride. Three tongue-like branches of the zone III waters are recognized in the eastern flank of the Kamiyama (Fig. 1). It is seen in Fig. 2 that $\delta \mathrm{D}$ values of the Zone III waters are slightly higher than those of waters from the other zones, and $\delta^{18} \mathrm{O}$ values are definitely higher than those of the others.

Oki and Hirano (1970) postulated the existence of "high temperature dense steam (HTDS)" (White, 1957; White et al., 1971) at depths of the Hakone geothermal system and estimated its contribution to the zone III waters to be $25 \sim 30 \%$, assuming that HTDS contains only sodium chloride, and that sulfate ions of the zone III waters are supplied exclusively by the zone II waters. They also estimated the contribution of HTDS to the zone III waters on the basis of the enthalpy budget to be $17 \sim 23 \%$. Oki and Hirano (1974) later revised their value to $30 \sim 50 \%$ on the basis of chemistry. The validity of these figures will be discussed in a later section in view of isotopic data.

Zone IV waters are sodium chloride-bicarbonate-sulfate type or mixed type (Fig. 3). Oki and Hirano (1970) further divided zone IV waters occurring on the eastern side of the caldera into two subgroups, IV a and IVb; the former occurs at higher levels in the Quaternary volcanic rocks around the central cones and the latter in the Yugashima group, the Miocene basement rocks at lower levels.

The chloride content is plotted against $\delta^{18} \mathrm{O}$ for thermal water as shown in Fig. 4 . It is clear that zone III waters with a few exceptions have the highest $\delta^{18} \mathrm{O}$ and chloride content, and that zone IV waters result from mixing of zone II and III waters. The results of isotopic 
analyses agree quite well with the chemical zoning of thermal waters in the Hakone geothermal system.

\section{ISOTOPIC EVIDENCE FOR THE Dissolved Materials}

The results of sulfur and oxygen isotopic analyses of sulfate ions dissolved in the various types of thermal waters are given in Table 5, together with some additional sulfur isotopic results for sulfur-bearing gases from the steam wells. Figure 5 shows the isotopic relationship between oxygen and sulfur of dissolved sulfate. There is a positive correlation between $\delta^{18} \mathrm{O}_{\mathrm{SO}_{4}}$ and $\delta^{34} \mathrm{~S}_{\mathrm{SO}_{4}}$ values, with a trend that the sulfate in zone I and II waters is isotopically lighter

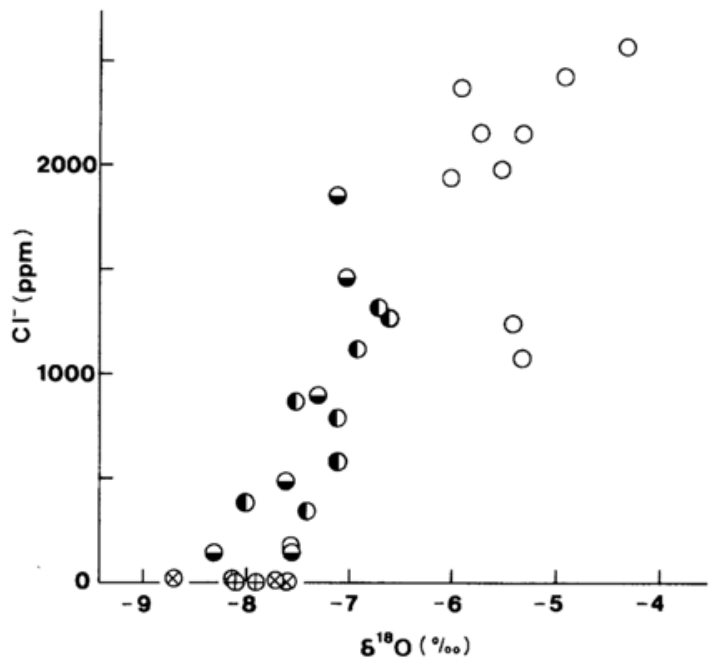

Fig. 4. Relationship between chloride content and $\delta^{18} O$ value of the thermal waters. Symbols are the same as those in Figs. 1 and 2.

Table 5. Sulfur, oxygen and carbon isotopic composition of dissolved sulfate and bicarbonate of thermal waters, and sulfur-bearing gases from steam wells in the Hakone geothermal system

\begin{tabular}{|c|c|c|c|c|c|c|}
\hline \multirow{2}{*}{\multicolumn{2}{|c|}{ Sample }} & \multicolumn{3}{|c|}{$\mathrm{SO}_{4}^{2-}$} & \multicolumn{2}{|c|}{$\mathrm{HCO}_{3}^{-}$} \\
\hline & & $\begin{array}{l}\text { conc. } \\
\text { (ppm) }\end{array}$ & $\begin{array}{l}\delta^{34} \mathrm{~S} \\
(\mathrm{CDT})\end{array}$ & $\begin{array}{l}\delta^{18} \mathrm{O} \\
\text { (SMOW) }\end{array}$ & $\begin{array}{l}\text { conc. } \\
\text { (ppm) }\end{array}$ & $\begin{array}{l}\delta^{13} \mathrm{C} \\
(\mathrm{PDB})\end{array}$ \\
\hline \multicolumn{7}{|c|}{ Hot spring water from zone I } \\
\hline \multicolumn{2}{|c|}{$\begin{array}{l}\text { Hot spring water from zone } \\
\text { I-1 }\end{array}$} & 405 & -3.2 & +0.3 & - & - \\
\hline \multicolumn{2}{|l|}{$\mathrm{I}-2$} & 502 & -3.4 & +0.1 & - & - \\
\hline \multicolumn{7}{|c|}{ Hot spring water from zone II } \\
\hline \multicolumn{2}{|c|}{ II-1 } & 551 & -2.2 & +3.2 & 121 & +0.4 \\
\hline \multicolumn{2}{|l|}{ II-2 } & 370 & +14.1 & +8.5 & 443 & +2.0 \\
\hline \multicolumn{2}{|l|}{ II-5 } & 202 & -2.5 & +3.0 & 113 & +2.1 \\
\hline \multicolumn{7}{|c|}{ Hot spring water from zone III } \\
\hline \multicolumn{2}{|c|}{ III-2 } & 93 & +5.8 & +2.0 & 196 & +1.0 \\
\hline \multicolumn{2}{|l|}{ III-3 } & 107 & +4.9 & +1.8 & 61 & -2.3 \\
\hline \multicolumn{7}{|c|}{ Hot spring water from zone IVa } \\
\hline \multicolumn{2}{|c|}{ IVa-1 } & 81 & +4.2 & +2.5 & 73 & +0.6 \\
\hline \multicolumn{2}{|l|}{ IVa-2 } & 174 & +6.7 & +4.1 & 254 & -0.2 \\
\hline \multicolumn{2}{|l|}{ IVa-8 } & 140 & +5.9 & +4.3 & 178 & -1.5 \\
\hline \multicolumn{2}{|l|}{ IVa-9 } & 54 & +4.1 & +1.7 & 77 & -6.7 \\
\hline \multicolumn{7}{|c|}{ Hot spring water from zone IVb } \\
\hline \multicolumn{2}{|l|}{$\mathrm{IVb}-1$} & 34 & +12.1 & +5.9 & 51 & -12.1 \\
\hline \multicolumn{2}{|l|}{ IVb-2 } & 409 & +17.5 & +8.7 & 15 & -11.2 \\
\hline \multicolumn{2}{|l|}{ IVb-4 } & 127 & +10.0 & +6.6 & 25 & -14.1 \\
\hline \multicolumn{7}{|c|}{ Groundwater } \\
\hline \multicolumn{2}{|c|}{ GW-10 } & 193 & +7.2 & +5.4 & 43 & -6.4 \\
\hline \multicolumn{7}{|c|}{ Gases from steam well } \\
\hline \multirow[t]{4}{*}{ CW-1 } & $\mathrm{H}_{2} \mathrm{~S}$ & & -5.3 & & & \\
\hline & $\mathrm{SO}_{2}^{*}$ & & -3.2 & & & \\
\hline & total sulfur & & -3.7 & & & \\
\hline & $\mathrm{CO}_{2}$ & & & & & $-0.7 * *$ \\
\hline \multirow[t]{3}{*}{$\mathrm{CW}-2$} & $\mathrm{H}_{2} \mathrm{~S}$ & & -4.0 & & & \\
\hline & $\mathrm{SO}_{2}^{*}$ & & +2.9 & & & \\
\hline & total sulfur & & 0.0 & & & \\
\hline
\end{tabular}

* sulfur compounds other than $\mathrm{H}_{2} \mathrm{~S}$.

** taken from Craig et al. (1978). 
(with an exception for the sample II-2), the sulfate in zone IVb waters heavier and the sulfate in zone III and IV a waters intermediate. Similar results have been given by Matsubaya et al. (1973) and Sakai and Matsubaya (1977). The range of $\delta^{34} \mathrm{~S}$ values of sulfur-bearing species from steam wells is indicated on a $\delta^{34} \mathrm{~S}$ axis of Fig. 5. Zone I waters are typical acid sulfate water. Such sulfate is considered to have resulted from the surface oxidation of volcanic sulfur at shallow depths where atmospheric oxygen is available. Bacterial oxidation of reduced sulfur to form sulfate in geothermal environments may also be possible (Mosser et al., 1973). Agreement of $\delta^{34} S$ values between the zone I sulfate and sulfur gases in volcanic steam from the Owakudani fumarolic area supports the view of supergene origin of the sulfate, since it has been known that the isotopic ratio of sulfur of reduced form is inherited by oxidized sulfur through oxidation processes (Sakai, 1957; Ivanov et al., 1968; Schoen and Rye, 1970).

When atmospheric oxygen is utilized in oxidative sulfate formation in an aqueous medium, the oxygen isotopic ratio of the resulting sulfate is determined by the isotopic ratios of both atmospheric and water oxygen with relative contribution of about $1 / 3$ and $2 / 3$, respectively (Lloyd, 1967). If the $\delta^{18} \mathrm{O}_{\mathrm{H}_{2} \mathrm{O}}$ values are taken to be $-8.5 \%$ for zone I waters (Table 1) and $23.5 \%$ for atmospheric oxygen (Kroopnick and Craig, 1972) with the kinetic fractionation factor of $-8.7 \%$ for the incorporation of atmospheric oxygen in the sulfate (Lloyd, 1967), then the resulting sulfate should have the $\delta^{18} \mathrm{O}$ value of about $-0.7 \%$, which is in good agreement with the observed values of $0 \%$ for sulfate in zone I waters.

Similarity in sulfur isotopic ratios in zone I and II waters (excluding II-2) suggests that sulfate in zone II waters may also have a similar origin. In other words, acid zone I waters are neutralized during permeation through the central cone materials to form zone II waters which occur about several hundred meters below the zone I level, forming a major aquifer
(Oki and Hirano, 1970). The fact that the $\delta^{18} \mathrm{O}_{\mathrm{SO}_{4}}$ values of zone II waters are slightly higher than those of zone I waters is due probably to partial oxygen isotopic exchange with water in which the sulfate is dissolved. The dissolved sulfate should have $\delta^{18} \mathrm{O}$ value of about $+9 \%$, if complete equilibrium was attained in water with $\delta^{18} \mathrm{O}_{\mathrm{H}_{2} \mathrm{O}}=-8 \%$ at $100^{\circ} \mathrm{C}$ (Mizutani and Rafter, 1969). Recent studies on reaction kinetics show that only partial equilibration is possible under low temperature $\left(100^{\circ} \mathrm{C}\right)$ and neutral to weakly acid ( $\mathrm{pH}$ down to 2) conditions encountered in the Hakone geothermal system (Chiba, pers. com.).

As mentioned previously zone III waters are considered to be formed by mixing of sulfaterich zone II waters with deeply generated dense steam carrying predominantly sodium chloride. Zone III and IV a waters are isotopically similar to each other as far as dissolved sulfate is concerned, suggesting a common origin. Both $\delta^{34} \mathrm{~S}_{\mathrm{SO}_{4}}$ and $\delta^{18} \mathrm{O}_{\mathrm{SO}_{4}}$ values of sulfate in these waters, however, are higher than those of zone I waters, and are close to those of a groundwater sample GW-10. According to a hydrogeochemical study of ground-waters in the Hakone caldera (Hirano and Oki, 1971), a shallow groundwater flow from which GW-10 was sampled is estimated to come down from zone I through the central cone debris. GW-10 contains sulfate as well as a measurable amount of ferrous ion with a $\mathrm{Fe}^{2+} / \mathrm{Fe}^{3+}$ ratio as high as 25. Eh-pH calculations indicate that sulfate ion, rather than hydrogen sulfide, is the stable form of aqueous sulfur species under the redox and $\mathrm{pH}$ conditions estimated for GW-10 assuming attainment of equilibrium between $\mathrm{Fe}^{2+}$ and ferric hydroxide (Hirano and Oki, 1971). However, the solution can become more reducing during down-permeation through rocks containing ferrous minerals. Under such reducing conditions, dissolved sulfate can be reduced probably by anaerobic bacteria. Bacterial reduction of sulfate is mostly accompanied by the enrichment of heavier isotopes in the remaining sulfate (Mizutani and Rafter, 1973), to which isotopic enrichment observed for 
sulfate in zone III and IV a waters relative to that in zone II water may be ascribed.

If $\mathrm{HCO}_{3}^{-}$in the Hakone hot spring waters is derived from decomposition of fossil organic materials intercalated in the volcanic rocks as was proposed by Oki and Hirano (1970), its $\delta^{13} \mathrm{C}$ values are expecred to be close to those of terrestrial plants which are typically in the range of -20 to $-25 \%$ (PDB). Carbon isotopic analyses given in Table 5, however, show existence of isotopically much heavier $\mathrm{HCO}_{3}^{-}$. The average $\delta^{13} \mathrm{C}$ value of $-0.5 \pm 2.7 \%$ for $\mathrm{HCO}_{3}^{-}$dissolved in zone II, III and $\mathrm{IV}_{\mathrm{a}}$ waters indicates only small contribution of $\mathrm{CO}_{2}$ of organic origin. This average value is consistent with a $\delta^{13} \mathrm{C}$ value of $-0.7 \%$ for $\mathrm{CO}_{2}$ in the zone II steam well (CW-1) reported by Craig et al. (1978). The above isotopic evidence suggests that the ultimate source of carbon in the zone II, III and IVa waters is sought in marine carbonates which occur as secondary minerals in the Yugashima formation, the Miocene basement of submarine basalts and andesites underlying the Hakone caldera. The $\mathrm{CO}_{2}$ may have been carried up from the depths upon decomposition of carbonate and dissolved in groundwater at the uppermost part of the Hakone geothermal system. Such carbonate-rich water may be mixed with descending sulfate-bearing ground waters to give isotopically heavy $\mathrm{HCO}_{3}^{-}$ rich waters in zones II and III.

Zone IVb waters form a group characterized by sulfate with high oxygen and sulfur isotopic ratios as shown in Fig. 5. Concentration of $\mathrm{HCO}_{3}^{-}$in these waters is low and its $\delta^{13} \mathrm{C}$ value is more negative than the others (Table 5), indicating higher contribution of organically derived carbon. These waters occur at the lowest elevation of the Hakone geothermal system, where the Yugashima formation is exposed. It is most likely that the zone IVb sulfate was leached out of the Yugashima formation which contains sulfate as anhydrite (or gypsum) with $\delta^{34} \mathrm{~S}$ values of $+15 \sim+16 \%$ (Mizutani et al., 1975, Matsubaya et al., 1973). The points for zone $\mathrm{IVb}$ waters extend towards lower $\delta^{18} \mathrm{O}_{\mathrm{SO}_{4}}$ and $\delta^{34} \mathrm{~S}_{\mathrm{SO}_{4}}$ values in Fig. 5, implying mixing of down-permeating sulfate with lower isotopic ratios as discussed previously.

\section{Origin OF THE Thermal Water}

Estimation of isotopic composition of HTDS

The hghest fumarolic activity in the caldera is seen in the Owakudani area, about $1,000 \mathrm{~m}$ above sea level at the northern slope of the Kamiyama, one of the central cones. There are several steam wells of which highest temperature is $180^{\circ} \mathrm{C}(\mathrm{CW}-2)$ and natural fumaroles with boiling temperature of water. The thermal output due to steam and hot water discharge of this area, $1.1 \times 10^{7} \mathrm{cal} \cdot \mathrm{s}^{-1}$ (Yuhara, 1968) is about one third to one half of the entire thermal output from the Hakone geothermal system (Oki and Hirano, 1970). There is also a fumarolic area in the So-unzan area at the north-eastern flank of the Kamiyama, where several shallow steam wells are installed. The temperature of steam from this area is slightly less than $100^{\circ} \mathrm{C}$. There are two steam wells in the Yunohanazawa area at about $1,000 \mathrm{~m}$ level of the eastern slope of the Komagatake, one of the central cones.

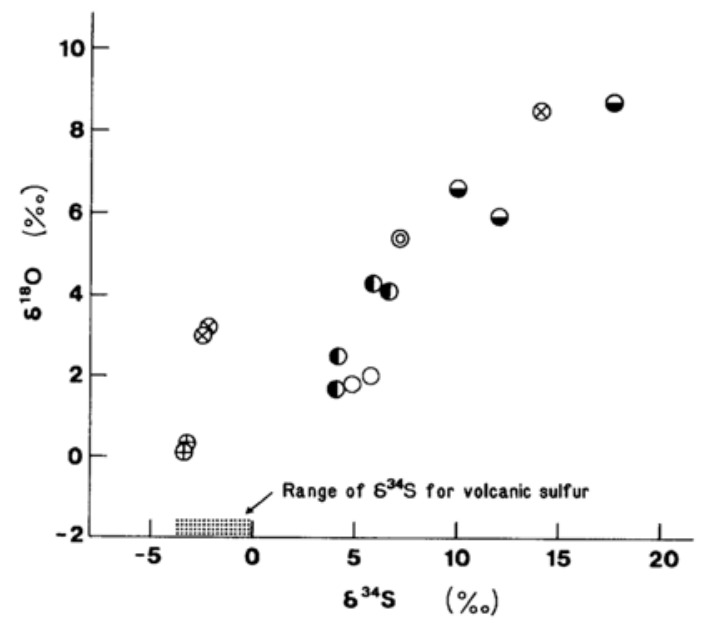

Fig. 5. $\delta^{18} O$ versus $\delta^{34} S$ plot of dissolved sulfate in the Hakone thermal waters. The range of $\delta^{34} S$ values for sulfur from the steam wells is given on a horizontal axis for comparison. Symbols are the same as those in Figs. 1 Fig. 2. 
Since the steam discharge from the Owakudani area is the greatest in the caldera as far as thermal output is concerned, the following discussion will mainly be based on the isotopic data of steam condensate from the Owakudani area (CW-2), which exhibits the highest $\delta \mathrm{D}$ and $\delta^{18} \mathrm{O}$ values among all the Hakone samples studied.

The high $\delta \mathrm{D}$ and $\delta^{18} \mathrm{O}$ values of the Owakudani steam (CW-2) suggest a close relationship between $\mathrm{CW}-2$ steam and HTDS. The average values of $\mathrm{CW}-2$ (a triangle at the far right end of Fig. 2), however, do not lie on the extension of the thermal water line, $\delta \mathrm{D}=2.1 \delta^{18} \mathrm{O}-33.5$, but slightly above the line. Yuhara (1968) estimated the temperature of subsurface reservoir of hot water beneath the central cones to be as high as $240^{\circ} \mathrm{C}$ on the basis of the enthalpy measurement of the steam. We estimated the isotopic composition of the liquid in the reservoir to be $\delta \mathrm{D}=-26 \%$ and $\delta^{18} \mathrm{O}=+3 \%$, assuming the isotopic exchange equilibrium between the liquid and steam with the average observed isotopic composition of $\delta \mathrm{D}=-25 \%$ and $\delta^{18} \mathrm{O}=+1 \%$, with the help of the liquidvapor fractionation factors at $240^{\circ} \mathrm{C}$ given by Bottinga and Craig (1968). This set of values for the liquid lies just on the extention of the thermal water (liquid) line in Fig. 2. Let us assume here that the liquid water with $\delta \mathrm{D}=$ $-26 \%$ and $\delta^{18} \mathrm{O}=+3 \%$ is a subsurface condensate of HTDS derived from a depth.

We can now set the isotopic ratios of the two extremes, i.e., HTDS and RGW to be $\delta \mathrm{D}=$ $-26 \%, \delta^{18} \mathrm{O}=+3 \%$ and $\delta \mathrm{D}=-51 \%, \delta^{18} \mathrm{O}=$ $-8.5 \%$, respectively. As mentioned already zone III waters are the mixture of HTDS and RGW. The contribution of HTDS to zone III waters is then calculated to be $25 \%$, ranging from 20 to $36 \%$, reflecting a slight change in isotopic ratios of zone III water. This estimate agrees well with the HTDS contribution of $30 \%$ estimated by Oki and Hirano (1970) on the basis of the chemistry of zone III waters. When the chloride content of zone III waters and mixing ratio of HTDS to zone III waters are taken to be respectively $2,500 \mathrm{ppm}$ and $25 \%$, the chloride content of HTDS is estimated to be $10,000 \mathrm{ppm}$.

According to our latest experimental results (Shinohara et al., 1984) chlorine bearing species in the steam phase coexisting with acidic silicate melt saturated with water are mostly $\mathrm{NaCl}$ with much less $\mathrm{HCl}$, in the range from the total pressure of 1 to $6 \mathrm{~kb}$ at the temperature of $800 \sim 900^{\circ} \mathrm{C}$. So that the steam derived from a deep-seated magma can contain a significant amount of NaCl. According to Sourirajan and Kennedy (1962), the vapor with the temperature higher than $390^{\circ} \mathrm{C}$ with the pressure higher than $150 \mathrm{~b}$ can contain $10,000 \mathrm{ppm}$ of chloride ions in the form of $\mathrm{NaCl}$. A large proportion of HTDS with the minimum temperature of $390^{\circ} \mathrm{C}$ encounters the major aquifer of RGW to form zone III waters. A small portion of HTDS, however, ascends through conduits without mixing with RGW aquifer and condenses at a shallower and cooler place to form a liquid reservoir at the temperature around $240^{\circ} \mathrm{C}$ beneath the Owakudani area. The isotopic composition of HTDS may be taken to be the same as that of the $240^{\circ} \mathrm{C}$ reservoir which has been estimated above. Most of the dissolved $\mathrm{NaCl}$ in HTDS should be left behind during the ascent owing to the temperature drop from 390 to $240^{\circ} \mathrm{C}$ to form the final liquid reservoir. So that chlorine-bearing compounds in the final reservoir should be mostly $\mathrm{HCl}$. On the other hand, the concentration of volatile components such as $\mathrm{HCl}$ and $\mathrm{H}_{2} \mathrm{~S}$ in HTDS is almost kept unchanged before the condensation occurs. The steam from the subsurface liquid reservoir reaches the surface to reveal fumarolic activity. The acid gases explain low pH of 1 to 2 of the steam condensate, $\mathrm{CW}-2$.

Origin of HTDS The estimated values of $\delta \mathrm{D}=-26 \%$ and $\delta^{18} \mathrm{O}=+3 \%$ of HTDS can be compared with $\delta \mathrm{D}=-25$ to $-30 \%$ and $\delta^{18} \mathrm{O}$ $=+8 \%$ of the deep-lying hot brine of the Arima hot spring area, Hyogo Pref., Japan, estimated by Matsubaya et al. (1974), a narrow range centered at $\delta \mathrm{D}=-25 \%$ and $\delta^{18} \mathrm{O}=+7 \%$ of high temperature fumarolic gas condensates of 
Satsuma-Iwojima, off south end of Kyushu, Japan, measured by Matsuo et al. (1974) and Matsubaya et al. (1975), and $\delta \mathrm{D}=-28$ to $+6 \%$ and $\delta^{18} \mathrm{O}=+7 \%$ of steam condensates from White Island fumaroles, New Zealand (Stewart and Hulston, 1975).

When we assume that the difference in $\delta^{18} \mathrm{O}$ values of the above cited thermal waters is due to the difference in the extent of rockwater interaction at different temperatures, $\delta^{18} \mathrm{O}$ of the deep thermal waters gives us no definite information on the ultimate origin of the deep thermal waters. On the other hand, the similarity in $\delta \mathrm{D}$ values for the above cited systems may be an interesting problem to be solved. The similarity in $\delta \mathrm{D}$ values, however, does not imply the direct contribution of "juvenile water", since there is no positive reason to imagine that the upper mantle beneath active zones such as Japanese and New Zealand island arcs has retained the juvenile water throughout its histories and the mantle water is estimated to have $\delta \mathrm{D}$ values between -90 and $-75 \%$ (Matsuo et al., 1978). The facts that high ${ }^{3} \mathrm{He} /{ }^{4} \mathrm{He}$ ratio of the gas from $\mathrm{CW}-1$ of 8.6 $\times 10^{-6}$ is about six times as high as the atmospheric value of $1.4 \times 10^{-6}$ and that $\mathrm{He} / \mathrm{Ne}$ ratio is 140 times higher than that of the atmosphere (Craig et al., 1978), however, indicate that most of the helium must have derived from the juvenile helium retained in the mantle. This fact is a clear indication of the least contamination for the mantle helium during the degassing of mantle volantiles, in contrast to the overwhelmingly large contribution of local surface water that erases the isotopic signature of (juvenile?) water.

Why is the $\delta \mathrm{D}$ value of HTDS of the Hakone geothermal system $-26 \%$ ? We will present a model which may account for the origin of HTDS. The Hakone volcano (Pleistocene) is underlain by thick piles composed mostly of submarine pyroclastic sediments of the lower to middle Miocene (the Yugashima group). Common alteration products of this group are calcite, zeolites and chlorite (Kuno, 1950). When a fluid reaches the Yugashima group at depths, the fluid interacts with pre-existing hydrous silicates and changes its original $\mathrm{D} / \mathrm{H}$ ratio. The final $\delta \mathrm{D}$ value of the fluid should be $-26 \%$.

In order to check this possibility, rock samples of the Yugashima group were analyzed for $\mathrm{D} / \mathrm{H}$ ratio. Description of the samples and analytical results are given in Table 6 . The $\delta \mathrm{D}$ values of samples 1 and 2 in Table 6 can be considered to represent those of typical pre-existing hydrous silicates in the Yugashima group, and in this sense these samples are regarded as "fresh". Samples 3 and 4 with lower $\delta$ D values, on the other hand, can be considered to have been subjected to later interaction with recent thermal waters pertinent to the system. Thus samples 3 and 4 can be regarded as "altered" ones. Since chlorite is the predominant hydrous silicate mineral in the rock samples, chlorite can be considered to represent the hydrous silicates in the samples on the first approximation.

A close look at Table 6 reveals that the water content of the altered samples to be almost doubled as compared with that of the fresh

Table 6. Total water content and D/H ratio of hydrous silicates from the Yugashima group

\begin{tabular}{clcc}
\hline $\begin{array}{l}\text { Sample } \\
\text { number }\end{array}$ & \multicolumn{1}{c}{ Sample description } & $\begin{array}{c}\text { Water content } \\
\text { (bulk, } \%)\end{array}$ & $\begin{array}{c}\delta \mathrm{D} \\
(\%)\end{array}$ \\
\hline 1 & Typical Yugashima group at Atsugi (80m thick) & 1.63 & -55.0 \\
2 & $\begin{array}{l}\text { Core sample from the basement rock of the Hakone } \\
\text { area. Taken by Kuno which is located in the zone IVa } \\
209 \mathrm{~m} \text { deep }\end{array}$ & 1.27 & -53.1 \\
3 & $\begin{array}{l}\text { Core sample from the Yugashima group interacted with } \\
\text { the Hakone thermal water. Taken from Suzawa which } \\
\text { is located in the middle of zone III, 293m deep } \\
\text { Yugashima group interacted with the Yugawara thermal } \\
\text { water. Taken from Fudo-taki, Yugawara geothermal } \\
\text { area }\end{array}$ & 3.22 & -62.4 \\
4 & & 3.28 & -71.5 \\
\hline
\end{tabular}


samples. This indicates that during water-rock interaction a part of water was incorporated into the hydrous mineral phases to give a net increase in chlorite content of the altered samples. In a closed system we get the following isotopic material balance equation for the water-rock interaction,

$$
\begin{aligned}
\mathrm{W} \delta_{\mathrm{w}}^{\mathrm{i}}+\mathrm{C} \delta_{\mathrm{c}}^{\mathrm{i}}=(\mathrm{W} & -\Delta \mathrm{W}) \delta_{\mathrm{w}}^{\mathrm{f}} \\
& +(\mathrm{C}+\Delta \mathrm{W}) \delta_{\mathrm{c}}^{\mathrm{f}}
\end{aligned}
$$

where $\mathrm{W}$ and $\mathrm{C}$ are the number of hydrogen atoms of water and chlorite, respectively, $\Delta \mathrm{W}$ the increase of chlorite hydrogen at the expense of the equivalent amount of water, and i, f, c and $\mathrm{w}$ denote initial, final, chlorite and water, respectively. If we assume attainment of hydrogen isotopic exchange equilibrium, the following relation holds,

$$
\delta_{\mathrm{c}}^{\mathrm{f}}-\delta_{\mathrm{w}}^{\mathrm{f}}=10^{3} \ln \alpha
$$

where $\alpha$ is the fractionation factor between chlorite and water. Since the water content of the altered samples is twice as much as that of the fresh samples,

$$
\frac{\mathrm{C}+\Delta \mathrm{W}}{\mathrm{C}} \simeq 2
$$

Combining equations (1), (2) and (3), we get

$$
\frac{\mathrm{C}}{\mathrm{W}}=\frac{\delta_{\mathrm{w}}^{\mathrm{f}}-\delta_{\mathrm{w}}^{\mathrm{i}}}{\delta_{\mathrm{c}}^{\mathrm{i}}-\delta_{\mathrm{w}}^{\mathrm{f}}-2 \times 10^{3} \ln \alpha}
$$

We can now put the following values into equation (4); $\delta_{\mathrm{c}}^{\mathrm{i}}=-54 \%$ for the fresh chlorite (average of samples 1 and 2) and $\delta_{w}^{f}=-26 \%$ for $\delta \mathrm{D}$ of HTDS. $10^{3} \ln \alpha$ for the chlorite-water system can be found in Taylor (1974) and Marumo et al. (1980), and the value of -40 for the temperature around $400^{\circ} \mathrm{C}$ is tentatively taken for the purpose of calculation.

Since the $\mathrm{C} / \mathrm{W}$ ratio is positive, $\delta_{\mathrm{w}}^{\mathrm{f}}-\delta_{\mathrm{w}}^{\mathrm{i}}$ should also be positive, i.e., $\delta_{w}^{i}$ should be more negative than $-26 \%$. From fhis, the water with relatively high $\delta \mathrm{D}$ values such as seawater (fossil or present-day) cannot be considered to be the candidate for the initial water. For the same reason, the 1:1 mixture of sea water and RGW, which gives chloride content of $\sim 10,000 \mathrm{ppm}$ (the estimated chloride content of HTDS), can also be excluded. If we assume RGW as the initial water whose $\delta \mathrm{D}$ value is $-51 \%$, however, $\mathrm{C} / \mathrm{W}$ ratio is calculated to be 0.5 , which roughly corresponds to a weight ratio of rock to water of 14 for the rock containing $30 \%$ chlorite by weight. The rock/water weight ratio $(\mathrm{R} / \mathrm{W})_{\mathrm{w}}$ estimated above is higher than those for the Salton Sea $\left((\mathrm{R} / \mathrm{W})_{\mathrm{w}}=2\right.$, Clayton et al., 1968) and Wairakei $\left((\mathrm{R} / \mathrm{W})_{\mathrm{w}}=0.2\right.$, Clayton and Steiner, 1975) geothermal systems, indicating the Hakone geothermal system to be more rockdominated.

The above results show that RGW can be a source water of HTDS. If this is the case, $\delta \mathrm{D}$ value of the altered chlorite should be $-66 \%$, since $\delta_{c}^{\mathrm{f}}-\delta_{\mathrm{w}}^{\mathrm{f}}=10^{3} \ln \alpha=-40$. The hydrous silicates in the Yugashima group which have interacted with the thermal waters give $\delta \mathrm{D}$ values of $-62 \%$ (sample 3 in Table 6) and $-72 \%$ (sample 4 in Table 6), which are in good agreement with the estimated value.

Oxygen isotopic material balance can be expressed in a form simpler than the case of hydrogen isotopes as follows,

$$
\mathrm{W} \delta_{\mathrm{w}}^{\mathrm{i}}+\mathrm{R} \delta_{\mathrm{r}}^{\mathrm{i}}=\mathrm{W} \delta_{\mathrm{w}}^{\mathrm{f}}+\mathrm{R} \delta_{\mathrm{r}}^{\mathrm{f}}
$$

where $\mathrm{W}$ and $\mathrm{R}$ denote respectively the number of oxygen atoms of water and rock including not only hydrous silicates but also other rockforming minerals, $\delta_{\mathrm{r}}^{\mathrm{i}}$ stands for initial $\delta^{18} \mathrm{O}$ value of the rock, and other notations are the same as those in equation (1) but hydrogen is replaced by oxygen. Equation (5) can be rewritten as follows using oxygen isotope fractionation factor, $10^{3} \ln \alpha$, between rock an water,

$$
\frac{\mathrm{R}}{\mathrm{W}}=\frac{\delta_{\mathrm{w}}^{\mathrm{f}}-\delta_{\mathrm{w}}^{\mathrm{i}}}{\delta_{\mathrm{r}}^{\mathrm{i}}-\delta_{\mathrm{w}}^{\mathrm{f}}-10^{3} \ln \alpha}
$$

The numerator of equation (6), $\delta_{w}^{\mathrm{f}}-\delta_{\mathrm{w}}^{\mathrm{i}}$, is socalled oxygen isotopic shift of water, and the 
value of $11.5 \%$ corresponding to the isotopic difference between HTDS and RGW can be allotted. If we further assume $\delta_{r}^{i}=+7 \%$ for the initial rock, $\delta_{\mathrm{w}}^{\mathrm{f}}=+3 \%$ for the final water (HTDS) and $10^{3} \ln \alpha=2$ which is the fractionation factor for the system plagioclase $\left(\mathrm{Ab}_{50} \mathrm{An}_{50}\right)$ water at $400^{\circ} \mathrm{C}$ (O’Neil and Taylor, 1967) in equation (6), then $\mathrm{R} / \mathrm{W}$ is calculated to be 5.8 . This value corresponds roughly to rock/water weight ratio of 11.5 , which is close to the value estimated from the hydrogen isotopic evidence and shows that the Hakone geothermal system is rock-dominated, probably owing to the limited supply of RGW in the caldera which is an independent hydrological unit (Matsuo et al., 1979).

On these bases, we conclude that the ultimate source of HTDS is meteoric in origin of which isotopic composition is similar to that of RGW. A schematic presentation of our con-

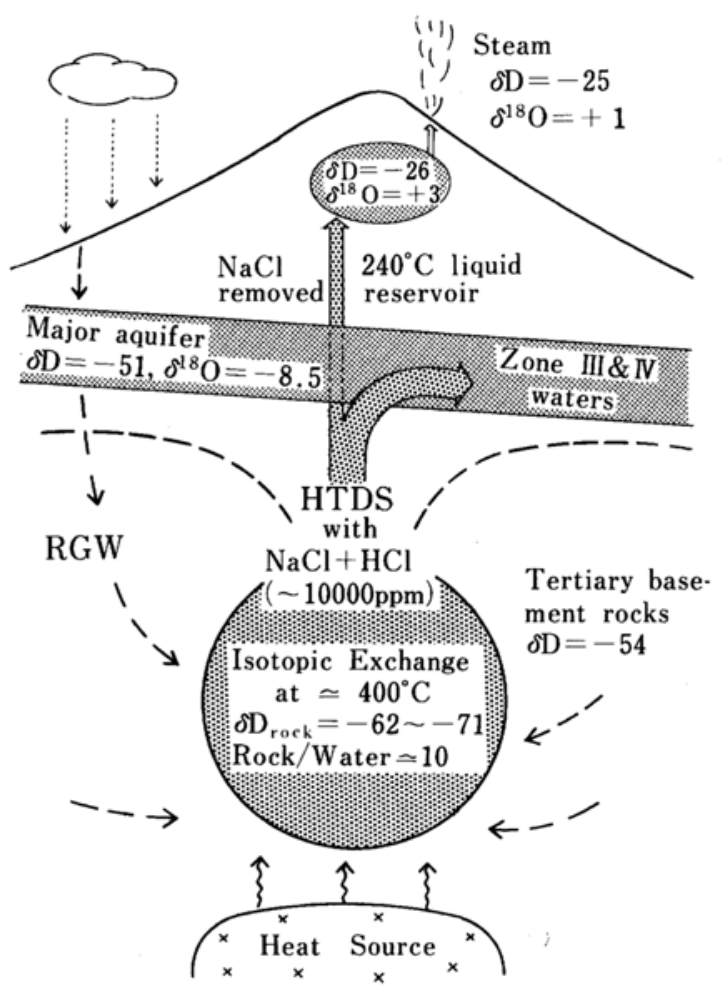

Fig. 6. A schematic presentation of a genetic model for the thermal waters in the Hakone geothermal system. See text for details. clusion is shown in Fig. 6. The present results suggest that thermal and volcanic waters with $\delta \mathrm{D}$ values as high as -30 to $-20 \%$ often observed for thermal water system (see the beginning part of section "Origin of HTDS") may have been evolved from hydrothermal interaction of meteoric water with rocks containing hydrous silicates.

Acknowledgement-This paper has been influenced by discussion with many colleagues and associates. The authors feel particularly indebted to Dr. O. Matsubaya of Akita University and Dr. H. Sakai of Ocean Research Institute, Tokyo University for invaluable comments. Thanks are extended to Mrs. Y. Matsuhisa, Miss K. Fuwa and Mr. Y. Tsutaki for their help in laboratory experiments and to staff members of the Hot Springs Research Institute of Kanagawa Pref. for their help and cooperation during the field work. Isotopic analyses of sulfate were carried out at the Institute of Nuclear Sciences, D.S.I.R., New Zealand while one of the authors (M.K.) was staying there. The authors are grateful to Dr. I. Friedman of U.S. Geological Survey, Denver, U.S.A., Dr. M. K. Stewart of Institute of Nuclear Science, D.S.I R., New Zealand, Dr. E. Mazor of Weizmann Institute of Science, Israel, and Dr. T. M. Gerlach of the Sandia National Laboratories, Albuquerque, U.S.A. for critical reading of the earlier version of the manuscript. The authors thank Miss M. Kambayashi and Y. Matsuzawa for their cooperation during the preparation of the manuscript.

A part of the expense of this study was defrayed by the Grant in Aid for Scientific Research from the Ministry of Education, Science and Culture of Japan, and the Grant from Kanagawa Prefecture.

\section{REFERENCES}

Bigeleisen, J., Perlman, M. L. and Prosser, H. C. (1952) Conversion of hydrogenic materials to hydrogen for isotope analysis. Anal. Chem. 24, 1356-1357.

Bottinga, Y. and Craig, H. (1968) High temperature liquid-vapor fractionation factors for $\mathrm{H}_{2} \mathrm{O}-\mathrm{HDO}$ $\mathrm{H}_{2}{ }^{18}$ O. Trans. Am. Geophys. Union 49, 356-357.

Clayton, R. N., Muffler, L. J. P. and White, D. E. (1968) Oxygen isotope study of calcite and silicates of the River Ranch No. 1 well, Salton Sea geothermal field, California. Am. J. Sci. 266, 968-979.

Clayton, R. N. and Steiner, A. (1975) Oxyten isotope studies of the geothermal system at Wairakei, New Zealand. Geochim. Cosmochim. Acta 39, 11791186. 
Craig, H., Boato, G. and White, D. E. (1956) Isotopic geochemistry of thermal waters. Proc. 2nd Conf. Nucl. Proc. Geol. Settings, 29-38.

Craig, H., Lupton, J. E. and Horibe, Y. (1978) A mantle helium component in circum-Pacific volcanic gases: Hakone, the Marianas, and Mt. Lassen. Terrestrial rare gases. Edited by E. C. Alexander, Jr. and M. Ozima, 3-16, Center for Academic Publications Japan.

Deuser, W. G. and Hunt, J. M. (1969) Stable isotope ratios of dissolved inorganic carbon in the Atlantic. Deep-Sea Res. 16, 221-225.

Friedman, I. and Smith, G. I. (1970) Deuterium content of snow cores from the Sierra Nevada area. Science 169, 467-470.

Fiedman, I. and Smith, G. I. (1972) Deuterium content of snow as an index to winter climate in the Sierra Nevada area. Science 176, 790-793.

Hirano, T. and Oki, Y. (1971) Geochemistry of groundwaters of Hakone caldera. Bull. Hot Spring Res. Inst., Kanagawa Pref. 2, 89-108 (Janaese).

Hirano, T. and Tajima, Y. (1969) Geochemistry of the Ubako hot springs, Hakone volcano. Bull. Hot spring Res. Inst., Kanagawa Pref. No. 8, 13-22 (Japanese).

Hirano, T. and Tajima, Y. (1970) Tables of chemical analysis of mineral waters (1966-1969) from the Hot Spring Research Institute of Kanagawa Prefecture, Part 2, Bull. Hot Spring Res. Inst., Kanagawa Pref. No. 10, 1-54 (Japanese).

Hirano, T., Oki, Y. and Awaya, T. (1972) Geochemistry of hydrothermal system of the Yumoto-Tonosawa Area, the eastern foot of Hakone volcano. Bull. Hot Spring Res. Inst., Kanagawa Pref. 3, 109-130 (Japanese).

Hirano, T., Oki, Y. and Tajima, Y. (1968) Effect of anomalous temperature on the chemical composition of thermal water, Gōra hot springs, the Hakone volcano. Bull. Hot Spring Res. Inst., Kanagawa Pref. No. 6, 51-62 (Japanese).

Hirota, S. and Odaka, S. (1975) Continuous observation of temperatures and water-levels in the Hakone volcano, 1974. Bull. Hot Spring Res. Inst., Kanagawa Pref. 6, 79-86 (Japanese).

Ivanov, M. V., Grinenko, V. A. and Lein, A. Yu. (1968) Exogenic formation of sulfuric acid in fumarole fields of volcanoes of the Kurile Islands. Geochem. Int. 9, 1133-1140.

Kroopnick, P. and Craig, H. (1972) Atmospheric oxygen: isotopic composition and solubility fractionation. Science 175, 54-55.

Kuno, H. (1950) Geology of Hakone volcano and adjacent areas, Part I. J. Fac. Sci., Univ. Tokyo, Sect. II 7, 257-279.

Kuno, H. (1951) Geology of Hakone volcano and adjacent areas, Part II. J. Fac. Sci., Univ. Tokyo. Sect. II 7, 351-402.

Kusakabe, M., Wada, H., Matsuo, S. and Horibe, Y. (1970) Oxygen and hydrogen isotopic ratios of monthly collected waters from Nasudake volcanic area, Japan. J. Geophys. Res. 75, 5941-5951.

Lloyd, R. M. (1967) Oxygen-18 composition of oceanic sulfate. Science 156, 1228-1231.

Marumo, K., Nagasawa, K. and Kuroda, Y. (1980) Mineralogy and hydrogen isotope geochemistry of clay minerals in the Onuma geothermal area. Earth Planet. Sci. Lett. 47, 255-262.

Matsubaya, O., Sakai, H. and Tsurumaki, M. (1974) Hydrogen and oxygen isotopic ratios of thermal and mineral springs in Arima area. Okayama Daigaku Onsen Kenkyusho Hokoku No. 43, 15-28 (Japanese).

Matsubaya, O., Sakai, H., Kusachi, I. and Satake, H. (1973) Hydrogen and oxygen isotopic ratios and major element chemistry of Japanese thermal water systems. Geochem. J. 7, 123-151.

Matsubaya, O., Ueda, A., Kusakabe, M., Matsuhisa, Y., Sakai, H. and Sasaki, A. (1975) An isotopic study of the volcanoes and the hot springs in SatsumaIwojima and some areas in Kyushu. Chishitsu Chosasho Geppo 26, 375-392 (Japanese).

Matsuo, S., Kuroda, Y., Suzuoki, T., Aoki, K. and Hariya, Y. (1978) Mantle water based on the hydrogen isotopic ratios of hydrous silicates in the mantle. Short Papers 4th Int. Conf. Geochronology, Cosmochronology and Isotope Geology, 278-280.

Matsuo, S., Kusakabe, M., Niwano, M., Hirano, T. and Oki, Y. (1979) Water budget in the Hakone caldera using hydrogen and oxygen isotope ratios. Isotopes in lake studies, 131-144. IAEA, Vienna.

Matsuo, S., Suzuoki, T., Kusakabe, M., Wada, H. and Suzuki, M. (1974) Isotopic and chemical compositions of volcanic gases from Satsuma-Iwojima, Japan. Geochem. J. 8, 165-173.

Mizutani, Y. (1971) An improvement in the carbonreduction method for the oxygen isotopic analysis of sulfates. Geochem. J. 5, 69-77.

Mizutani, Y., Asai, H. and Hamasuna, T. (1975) Origin of neutral chloride thermal waters from the southeastern part of Izu peninsula, Japan. Kazan 19, 139150 (Japanese).

Mizutani, Y. and Rafter, T. A. (1969) Oxygen isotopic composition of sulphates-Part 3. Oxygen isotopic fractionation in the bisulphate ion-water system. N. Z. J. Sci. 12, 54-59.

Mizutani, Y. and Rafter, T. A. (1973) Isotopic behaviour of sulphate oxygen in the bacterial reduction of sulphate. Geochem. J. 6, 183-191.

Moser, H. and Stichler, W. (1970) Deuterium measurement on snow samples from the Alps. Isotope 
hydrology, 43-57. IAEA, Vienna.

Mosser, J. L., Mosser, A. G. and Brock, T. D. (1973) Bacterial origin of sulfuric acid in geothermal habitats. Science 179, 1323-1324.

Oki, Y. and Hirano, T. (1970) The geothermal system of the Hakone volcano. Geothermics, Special Issue 2, 1157-1166.

Oki, Y. and Hirano, T. (1974) Hydrothermal system and seismic activity of Hakone volcano. The utilization of volcano energy. Edited by J. L. Colp and A. S. Furumoto, 13-40.

Oki, Y., Ogino, K., Hirota, S., Ohguchi, T. and Morita, M. (1968) Anomalous temperature encountered in the Gōra hydrothermal system of the Hakone volcano and its hydrological explanation. Bull. Hot Spring Res. Inst., Kanagawa Pref. No. 6, 1-20 (Japanese).

O'Neil, J. R. and Taylor, H. P., Jr. (1967) The oxygen isotope and cation exchange chemistry of feldspars. Am. Mineral. 52, 1414-1437.

Rafter, T. A. (1957) Sulphur isotopic variation in nature. Part 2, A quantitative study of the reduction of barium sulphate by graphite for recovery of sulphate-sulphur for sulphur isotopic measurements. N. Z. J. Sci., Technol. Sect. B 38, 955-968.

Robinson, B. W. and Kusakabe, M. (1975) Quantitative preparation of sulfur dioxide, for ${ }^{34} \mathrm{~S} /{ }^{32} \mathrm{~S}$ analyses, from sulfides by combustion with cuprous oxide. Anal. Chem. 47, 1179-1181.

Sakai, H. (1957) Fractionation of sulphur isotopes in nature. Geochim. Cosmochim. Acta 12, 150-169.

Sakai, H. and Matsubaya, O. (1974) Isotopic geochemistry of the thermal waters of Japan and its bearing on the Kuroko ore solutions. Econ. Geol. 69, 974-991.

Sakai, H. and Matsubaya, O. (1977) Stable isotopic studies of Japanese geothermal systems. Geothermics $5,97-124$.

Sato, K. (1962) On the thermal springs and geology of Izu-Hakone district. Onsen Kagaku 13, 41-51 (Japanese).

Savin, S. M. and Epstein, S. (1970) The oxygen and hydrogen isotope geochemistry of clay minerals. Geochim. Cosmochim. Acta 34, 25-42.

Schoen, R. and Rye, R. O. (1970) Sulfur isotope distribution in solfataras, Yellowstone National Park. Science 170, 1082-1084.

Shinohara, H., Iiyama, J. T. and Matsuo, S. (1984) Comportement du chlore dans le système magma granitique-eau. C. R. Acd. Sci. Paris 298, 741-743. Sourirajan, S. and Kennedy, G. C. (1962) The system $\mathrm{H}_{2} \mathrm{O}-\mathrm{NaCl}$ at elevated temperatures and pressures. Am. J. Sci. 260, 115-141.

Stewart, M. K. and Hulston, J. R. (1975) Stable isotope ratios of volcanic steam from White Island, New Zealand. Bull. Volcanol. 39, 28-46.

Tajima, Y. and Hirano, T. (1966) Tables of chemical analysis of mineral waters (1961-1966) from the Hot Spring Research Institute of Kanagawa Prefecture. Bull. Hot Spring Res. Inst., Kanagawa Pref. No. 3, 1-55 (Japanese).

Taylor, H. P., Jr. (1974) The application of oxygen and hydrogen isotope studies to problems of hydrothermal alteration and ore deposits. Econ. Geol. 69, 843-883.

Watanuki, K. (1966) Chemical composition of $\overline{0}_{\text {wa- }}$ kudani hot spring water, Hakone. Onsen Kagaku 17, 22-27 (Japanese).

White, D. E. (1957) Thermal waters of volcanic origin. Bull. Geol. Soc. Am. 68, 1637-1658.

White, D. E., Muffler, L. J. P. and Truesdell, A. H. (1971) Vapor-dominated hydrothermal systems compared with hot-water systems. Econ. Geol. 66, 75-97.

Yuhara, K., Kodai, K., Abe, K., Kotoda, K. and Hosono, Y. (1966) Hydrothermal system of ŌwakudaniGōra zone, Hakone volcano. Rep. Cooperative Res. Disaster Prevention No. 8, 29-42 (Japanese).

Yuhara, K. (1968) Quantitative estimation of hydrothermal system of Ōwakudani and Sōunzan geothermal areas, Hakone volcano. Kazan 13, 74-83 (Japanese). 